14 The excerpt begins "I have already said that Whitman is preparing an edition of his works in two volumes" and concludes "Whitman is the worst poet in the world to be judged by mere 'dipping,' or by any amount of extracts, however admirably chosen.”

15 Kate Field's Washington (April 6, 1892), 216.

16 The American philologist Richard Grant White had published an early Whitman parody in Albion (May 26, 1860), 249.

\title{
WHITMAN AND TEDDY ROOSEVELT: AN UNPUBLISHED WHITMAN PROSE MANUSCRIPT AT SAGAMORE HILL
}

At Sagamore Hill, Theodore Roosevelt's home on Long Island, there is a framed portrait of Whitman (an 1871 photograph by George G. Rockwood) accompanied by a manuscript fragment written, as many of the poet's manuscripts from the 1870 s are, on Department of Justice stationery. The stationery reads "Department of Justice, Office of the Solicitor of the Treasury, Washington, D. C., 187_." The manuscript itself (reprinted with the permission of Sagamore Hill) reads:

In science, we shall of course bear our part, in common with all civilized lands

\section{The geni}

The genius of Democratic America demands something rough, amp very ample not [^ too] delicate [^ not thinly "good,"] not too particular [^ and fierce, rank] something of the qualities of Roman Juvenal and Rabelais of France.

At present what is called literature is $\left[^{\wedge}\right.$ appears to be] in the hands of a lot of thin-blooded [^ rose-scented-] gentlemen, quite \& little better than dandies, gurgling \& in poetry and[?] full of intellee writing intellectual magazine articles \& criticism, wearisome enough every way.

This fragment joins Whitman's many other drafts of ideas that relate to notions he expressed in Democratic Vistas (1871) and elsewhere. Compare, for example, this fragment now in the Library of Congress:

The great themes of the Literatus are as common as the air, the light, the destinies, the pride love of man \& woman, and come home to all, like life $\&$ death. This writer is noble, but dainty. Not that he is of no value, for he is of measureless value. But he picks and rejects. Strictly speaking he belongs to the aristocracy Much is in his writings, and the young men of America are probably are debtors to them more, far more than to those of [illeg.] authors. But the lesson of Democracy, \& the lesson of the infinite and all-embracing amplitude of Nature $\&$ the Democracy of Nature $\&$ the application of that lesson to man, are not in them. He sometimes seems as if he would bravely approach these armored themes, where they stand[?] threatening in full panoply, \& do battle with them-but he never really does. Then he is, to speak it plainly, too genteel \& conventional - too dandified - no Juvenal, or Rabelais, or blurting Hebrew prophet. After their intellection, dainty suprciliousness seems with all the health \& sweetness be the unseen background of character to these writings (NUPM, 1757-1758). 
It is fitting that this Whitman material is on display at Sagamore Hill, since Roosevelt himself was fascinated with Whitman. John Burroughs recalled once trying without success to engage Roosevelt in a discussion about Whitman, whom he thought Roosevelt would like because both men were "equally hail-fellow-well-met with all kinds and classes of men," but he also realized "that one was in his very essence an autocrat, a leader, a ruler of men, while the other was in very essence a democrat whose interest in men was not to organize or rule them, ... or to reform them ... but to enrich and expand their souls. . . ." Burroughs went on to marvel that "two such widely diverse types should be the fruit of American democracy": "Of course the strenuous life could not appeal to Whitman personally, and equally, of course, the leisurely, half-indolent, sauntering life of contemplation and enjoyment could not appeal to Roosevelt." Still, in Outlook magazine (August 26, 1911), Roosevelt published an essay called "Dante and the Bowery," in which he offered this largely positive assessment of the American poet:

Of all the poets of the nineteenth century, Walt Whitman was the only one who dared use the Bowery-that is, use anything that was striking and vividly typical of the humanity around him - as Dante used the ordinary humanity of his day; and even Whitman was not quite natural in doing so, for he always felt that he was defying the conventions and prejudices of his neighbors, and his self-consciousness made him a little defiant. Dante was not defiant of conventions: the conventions of his day did not forbid him to use human nature just as he saw it, no less than human nature as he read about it. The Bowery is one of the great highways of humanity, a highway of seething life, of varied interest, of fun, of work, of sordid and terrible tragedy; and it is haunted by demons as evil as any that stalk through the pages of the "Inferno." But no man of Dante's art and with Dante's soul would write of it nowadays; and he would hardly be understood if he did. Whitman wrote of homely things and every-day men, and of their greatness, but his art was not equal to his power and his purpose; and, even as it was, he, the poet, by set intention, of the democracy, is not known to the people as widely as he should be known; and it is only the few-the men like Edward FitzGerald, John Burroughs, and W. E. Henley-who prize him as he ought to be prized.

Roosevelt copied out the first part of this statement and signed it for inclusion in Charles N. Elliot's Walt Whitman as Man, Poet and Friend (1915), a gathering of facsimile autograph pages from a wide variety of writers.

And Whitman himself seemed to be an admirer of the young Roosevelt. In 1888, he read one of Roosevelt's "ranche papers" about frontier life, written from his ranch in the Dakota territory where the young politician had gone on a temporary retreat from public life to recover from personal tragedy, hunt buffalo, and write (his four-volume The Winning of the West would be one eventual result). Whitman was impressed:

I like it: he gets pretty near the truth. He don't write it exactly as I would, of course: that's because he don't enter into it-puts on his glasses before he looks at it-writes it with a little the touch of a dude. Still, there is something alluring in the subject and the way it is handled: Roosevelt seems to have realized its character-its shape and size-to have honestly imbibed some of the spirit of that wild Western life. ${ }^{2}$ 
Like the two wary cultural giants they were, Whitman and Roosevelt each grudgingly admired the other, knowing they each would have said and done things differently but knowing too that they shared key values. Whitman even anticipated one of Rossevelt's signature expressions, when he wrote in the poem that he would eventually entitle "Crossing Brooklyn Ferry": "Bully for you! you proud, friendly, free Manhattanese!" Whitman had recorded the phrase in his early notebooks as one of the colorful expressions he heard among New York workers and Bowery boys, and it stayed in his poem until the 1870 edition of Leaves of Grass, when he omitted it. ${ }^{3} \mathrm{He}$ once toyed with the idea of writing a "poem of a proud, daring, joyous expression-for Manhattan island!," and calling it "Bully for you, Manhattan!"4 That's a manuscript we can imagine Roosevelt really would have desired, but the Whitman manuscript that he did own, with its demand for "something rough" in America and its disdain for "thin-blooded rose-scented gentlemen, dandies," would of course have appealed to the Rough Rider, even if he was never aware of Whitman's characterization of him as just a little too much the "dude."

Brooklyn, New York

Sherry Ceniza

The University of Iowa

Ed Folsom

Texas Tech University

Jerome Stueart

\section{NOTES}

1 Clara Barrus, Whitman and Burroughs: Comrades (Boston: Houghton Mifflin, 1931), 364.

2 Horace Traubel, With Walt Whitman in Camden (New York: D. Appleton and Company, 1908), 2:411.

3 Whitman records the phrase in $D B N, 669$. Whitman occasionally used the term himself, as in a November 1863 letter to Thomas P. Sawyer: "The elections went bully" (Corr., 1:186).

4 NUPM, 1327. William Sloane Kennedy in 1926 commented on Whitman's "Bully for you!" line: "I am sorry to say that our then immature poet exclaimed, á la Roosevelt:-'Bully for you!'” Kennedy, The Fight of a Book for the World (West Yarmouth, MA: Stonecroft Press, 1926), 167.

\section{WALT WHITMAN'S ADVICE TO NEW JERSEY STATE SCHOLARS: AN UNKNOWN INTERVIEW}

In February 1888, The Signal, the student newspaper of The College of New Jersey (then the New Jersey State Normal and Model Schools), published an interview with Walt Whitman titled "Walt Whitman's Advice to the State Scholars." The Signal came into existence in 1885, and two of its pioneers-George Worman, class of 1886, and Francis B. Lee, class of 1888-had traveled to Camden to conduct the interview with Whitman, soliciting advice for those state scholars who wished to follow the "literary life." The interview, the first 